\title{
Lymphocytic Chromosomal Instability in Sporadic Gastrointestinal Tract (GIT) Cancer Patients and their First-Degree Relatives
}

\author{
Pawandeep Kaur and Vasudha Sambyal \\ Department of Human Genetics, Guru Nanak Dev University, Amritsar 143 005, Punjab, India
}

KEYWORDS Sporadic; gastrointestinal cancer; first-degree relatives; chromosomal instability

\begin{abstract}
The present study was an attempt to assess utility of chromosomal instability in peripheral blood lymphocytes of first-degree relatives (FDR) of sporadic gastrointestinal tract (GIT) cancer patients for genetic surveillance. Standard lymphocyte culture technique was used for the purpose. Cultured peripheral blood lymphocyte metaphases were scored for aberrations in 10 sporadic cases of GIT cancer patients (6-esophageal, 1-gastric, 2-rectum and 1-cecum), 10 first-degree relatives and 10 healthy unrelated controls. There were significantly increased number of aberrations in cancer patients as compared to FDRs and controls. A perceptible increase in the level of metaphases with structural aberrations, including gaps, breaks, rings, centromeric separation and terminal deletions, was observed in first-degree relatives of cancer patients as compared to healthy unrelated controls taken from the same geographical area. There was high frequency of aberrations, mainly structural aberrations, involving specific chromosomes in firstdegree relatives and in cancer patients. Majority of aberrations were at chromosomal loci harboring genes involved directly or indirectly in tumorigenesis, thus indicating the probability of a constitutional chromosomal instability in first-degree relatives of even sporadic GIT cancer patients.
\end{abstract}

\section{INTRODUCTION}

Instability of genome plays an important role in tumor initiation and progression. Aneuploidy is proposed as the primary cause of genome instability of neoplastic and preneoplastic cells (Langauer et al. 1997). Aneuploidy destabilizes the karyotype and thus the species, independent of mutation, because it corrupts highly conser-ved team of proteins that segregate, synthesize and repair chromosomes. Likewise it destabilizes genes. The transition of stable diploid to unstable aneuploid cell species is apparently the primary cause of preneoplastic and neoplastic genomic instability and of cancer, and the mutations are secondary (Duesberg et al. 2004). Chromosomal instability, leading to loss of crucial portion of DNA or loss of a complete chromosome, may participate in cancer predisposition by causing a further loss of closely linked group of genes producing proteins essential for controlled cell division. An increased risk of cancer has been seen in healthy individuals, with high levels of chromosomal aberrations in peripheral blood

Address for correspondence: Dr. Vasudha Sambyal,

Reader, Human Genetics Department, Guru Nanak Dev

University, Amritsar-143 005, Punjab, India

Telephone: 0183-2258802-07 Ext. 3445

Fax: 0183-2258819

E-mail: vasudhasambyal@yahoo.co.in lymphocytes (Boffetta et al. 2007). A significantly elevated cancer risk was observed in a Nordic cohort for subjects with both high chromosome and chromatid-type aberrations in peripheral blood lymphocytes and these variables showed equally strong predictivity (Hagmar et al. 2004). There was no significant effect of modifications by age at test, gender, country or time since test observed on the association of cancer risk with increased chromosomal instability (Bonassi et al. 2000, 2004).

A wide range of chromosomal abnormalities and microsatellite instability have been reported in tumor tissue of gastrointestinal tract (GIT) cancer patients. These include disruption of APC gene, reciprocal translocations, gain and loss of chromosomes, and rearrangements in chromosomes 1, 2, 3, 4, 5, 8, 9, 10, 11, 16, 17, 18 and 19 (Bomme et al. 1996; Popat et al. 2003; Shiomi et al. 2003; Jin et al. 2004). Studies on family members and cancer patients from high risk families using peripheral blood lymphocytes, dermal fibroblast monolayer cultures and 8 blood markers did not yield any common biomarker shared by all family members at risk of developing cancer (DiLerina et al. 1987; Guanti et al. 1990). But increased in-vitro tetraploidy was reported in skin cultures derived from patients with colon cancer syndrome and some family members at risk (Danes, 1981). Increased endoreduplication and tetraploidy was also reported in lymphocytes 
of members of high risk cancer families for esophageal carcinoma (Wu, 1991). In patients with colorectal cancers and asymptomatic first degree relatives, increased numerical and structural aberrations involving chromosome 1 and 5 were observed (Dave et al. 1993). An increased chromosomal instability and increased expression of aphidicolin and bromodeoxyuridine (BrdU) inducible fragile sites were reported in relatives of individuals affected with gastro-intestinal tumors (Tunca et al. 2000). A mutagen-induced hypersensitivity and deficient DNA repair capacity was observed in unaffected relatives of colorectal cancer patients (Ankathil et al. 1999). A bleomycin induced mutagen hypersensitivity on specific chromosomes; especially chromosome 4 was reported in first degree relatives of cancer patients (Zhu et al. 2002). An increased allelic loss from chromosome $13 \mathrm{q}$ was found in esophageal cancer patients with positive family history (Hu et al. 2003). These studies establish the role of genetic instability associated with family history of cancer. A high incidence of aneuploidy and presence of premature separation of centromere was observed in lymphocytes and Epstein-Barr virus (EBV) transformed lymphoblastoid cell lines from first degree relatives of breast cancer patients (Rao et al. 1996). The association between chromosomal aberration frequency and cancer risk, in particular of stomach cancer was validated by a study of 11,991 subjects of Czech, French and Italian origin (Rossner et al. 2005).

Sporadic gastrointestinal tract cancer has an increased incidence in Amritsar district (Rotary Cancer Institute, Amritsar; unpublished data). The epidemiological factors for it are unclear and the risk for first-degree relatives of cancer patients is unknown in this particular population group. There is no surveillance done yet for firstdegree relatives.

The rationale of the present research is drawn from limited number of previous reports about lymphocytic chromosomal abnormalities in asymptomatic first-degree relatives of sporadic GIT cancer patients (Dave et al.1993; Ankhathil et al. 1999; Tunca et al. 2000 and Zhu et al. 2002) to assess the utility of chromosomal profile of cultured Peripheral blood lymphocytes for genetic surveillance.

\section{MATERIAL AND METHODS}

The lymphocytes of 10 sporadic cancer patients (6-esophageal, 1-gastric, 2-rectum and 1 -cecum), 10 healthy first-degree relatives and 10 healthy unrelated controls were analyzed for chromosomal aberrations. Blood samples were collected from cancer patients who had not yet undergone any treatment (surgery or chemotherapy and radiotherapy), their healthy asymptomatic relatives and controls with informed consent from Rotary Cancer Hospital, Vallah, Amritsar. The information about the subjects was collected on a pretested questionnaire. Standard lymphocyte culturing protocol (Moorehead et al. 1960) with slight modifications was used. Five $\mathrm{ml}$ of venous blood was drawn in heparinized syringe and kept at $4^{\circ} \mathrm{C}$ for 2 hours. For settingup of lymphocyte cultures, $8 \mathrm{ml}$ RPMI 1640 medium (Hi-Media), $0.15 \mathrm{ml}$ phytohaemagglutinin-M (PHA-M) (Gibco), $1.5 \mathrm{ml}$ autologous serum and cells from buffy coat were used. The lymphocytes were cultured for 71 hours. At $70^{\text {th }}$ hour $0.025 \mathrm{ml}$ of colcemid $(10 \mu \mathrm{g} /$ $\mathrm{ml}$; Sigma) was added to the culture. Culture was terminated one hour after adding colcemid. Cultured lymphocytes were given hypotonic treatment with $0.075 \mathrm{M} \mathrm{KCl}$ and then fixed with 3:1 methanol:acetic acid. For each case 5-6 slides were prepared and GTG banded (Benn and Perle 1986). In total, 100 well-spread metaphases were selected per subject after analyzing different slides of the subject. Selected metaphases were scored for aberrations under microscope. Chromosomal aberrations were classified using ISCN system of nomenclature (ISCN 2005). The student's t-test was used to compare the results statistically.

\section{RESULTS}

All the subjects belonged to Amritsar district, with their residence in villages adjoining main Amritsar city. These subjects were in the age group of 22-70 years. Their economic status was lower middle class or middle class with monthly income in the range of Rs. 3,000 to Rs. 10,000. They were taking vegetarian diet and were nonsmokers and non alcoholics. The FDRs and controls were healthy and not on any medications for at least two years prior to sampling.

Gross aberrations observed in the selected metaphases were polyploidy, aneuploidy, rings, chromatid and isochromatid gaps and breaks, terminal deletions, small fragments, double minutes, centromeric separations, fragmentations 


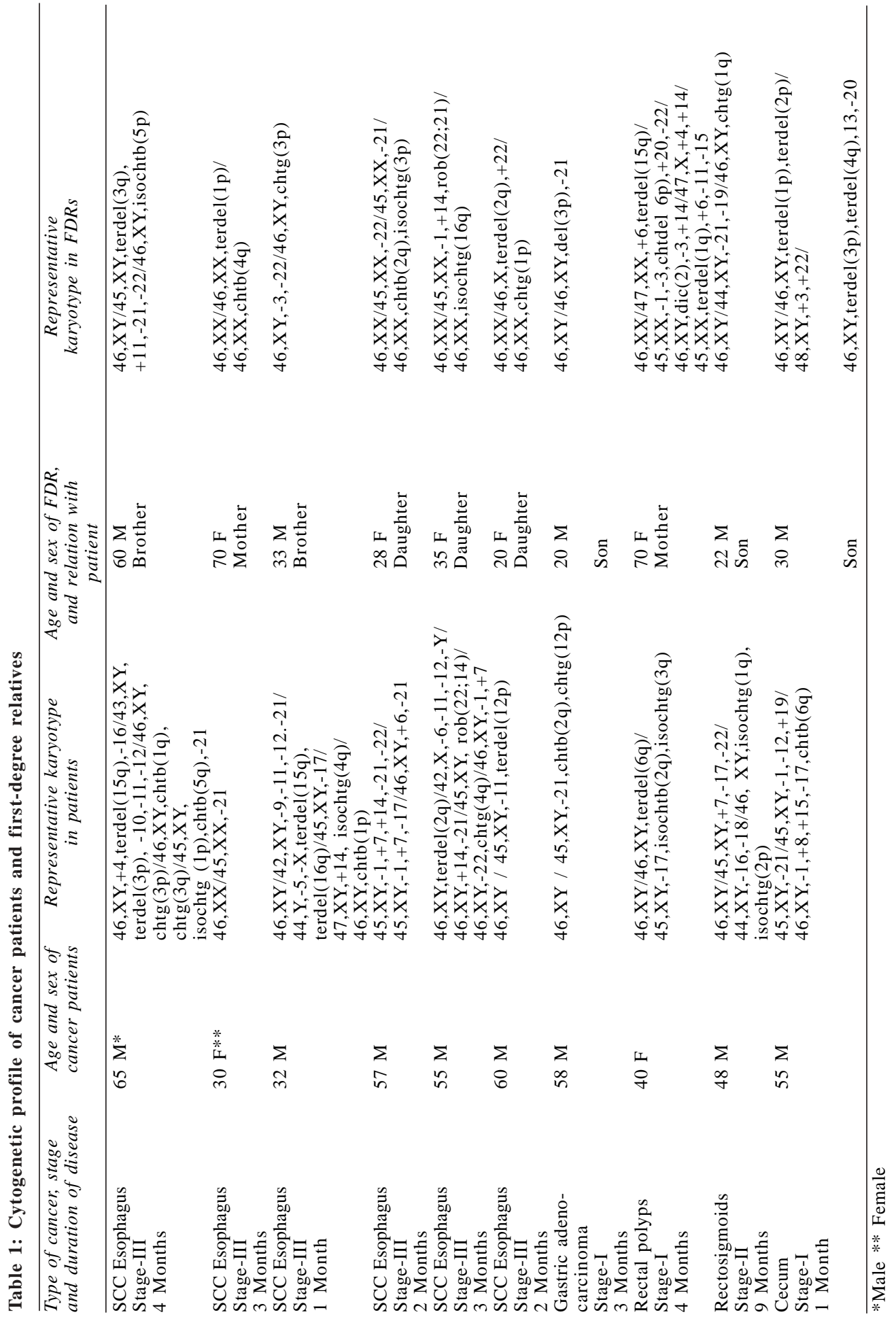


and acrocentric associations. The first-degree relatives showed aberrations in ' $A$ ' group chromosomes including terminal deletions of $1 \mathrm{p}$, $1 \mathrm{q}, 2 \mathrm{p}, 2 \mathrm{q}, 3 \mathrm{p}$, or $3 \mathrm{q}$, and loss of chromosome 1 and 3 . A loss of chromosome 21 and 22 was also observed. In first-degree relatives, chromosometype aberrations (numerical aberrations) were $40.17 \%$, chromatid-type aberrations (structural aberrations) were $28.75 \%$ and acrocentric associations were $39.13 \%$ in selected metaphases (Tables 1 and 2).

The cancer patients showed chromosometype aberrations in $41.03 \%$, chromatid-type aberrations in $23.96 \%$ and acrocentric associations in $47.88 \%$ of selected metaphases (Table 2). Six esophageal cancer patients showed loss of chromosomes 1, 2, 5, 6, 10, 11, 12, 14, 17,
21, 22, $\mathrm{X}$ and $\mathrm{Y}$, and terminal deletions in $2 \mathrm{q}, 3 \mathrm{p}$, $12 p, 15 q$ and 16q. Gastric cancer patient showed loss of chromosome 21. Chromatid gaps and breaks were seen in $12 p$ and $2 q$, respectively. Rectum cancer patients showed loss of chromosomes 17 and 22, and also terminal deletion of 6q. Cecum cancer patient showed loss of chromosome 1, 12,17 and 21, and gain of chromosomes 8,15,19 (Table 1).

Gross aberrations observed in lymphocytes of healthy unrelated controls were presence of chromatid gaps in chromosome 1 , breaks in chromosome 2 and centromeric separation in chromosomes 1, 2 and 3. Metaphases with numerical aberrations showed a frequency of $2.42 \%$, structural aberrations showed $1.25 \%$ and acrocentric association showed a frequency of

Table 2: Frequency of aberrations in cancer patients and their first-degree relatives (FDRs)

\begin{tabular}{|c|c|c|c|c|c|c|c|c|c|c|}
\hline \multirow{3}{*}{$\begin{array}{l}\text { Age and } \\
\text { sex of } \\
\text { cancer } \\
\text { patients }\end{array}$} & \multirow[t]{3}{*}{$\begin{array}{l}\text { Type of cancer } \\
\text { and duration }\end{array}$} & \multirow{3}{*}{$\begin{array}{l}\text { Age and sex } \\
\text { of FDR and } \\
\text { relation with } \\
\text { patient }\end{array}$} & \multirow{2}{*}{\multicolumn{2}{|c|}{$\begin{array}{l}\% \text { aberrant } \\
\text { metaphase }\end{array}$}} & \multicolumn{6}{|c|}{$\begin{array}{c}\% \text { specific aberrations among } \\
\text { the aberrant metaphases }\end{array}$} \\
\hline & & & & & \multicolumn{2}{|c|}{ Numerical } & \multicolumn{2}{|c|}{ Structural } & \multicolumn{2}{|c|}{$\begin{array}{l}\text { Acrocentric } \\
\text { associations }\end{array}$} \\
\hline & & & Patient & $F D R$ & Patient & $F D R$ & Patient & $F D R$ & Patient & $F D R$ \\
\hline $65 \mathrm{M}^{*}$ & $\begin{array}{l}\text { SCC Esophagus } \\
\text { Stage-III } \\
4 \text { Months }\end{array}$ & $\begin{array}{r}60 \mathrm{M} \\
\text { Brother }\end{array}$ & 56 & 29 & 67.85 & 41.37 & 8.9 & 20.68 & 35.7 & 44.82 \\
\hline $30 \mathrm{~F}^{* *}$ & $\begin{array}{l}\text { SCC Esophagus } \\
\text { Stage-III } \\
\text { Mother } \\
3 \text { Months }\end{array}$ & $70 \mathrm{~F}$ & 35 & 15 & 25.7 & 40 & 34.28 & 6.6 & 54.28 & 33.33 \\
\hline $32 \mathrm{M}$ & $\begin{array}{l}\text { SCC Esophagus } \\
\text { Stage-III } \\
1 \text { Month }\end{array}$ & $\begin{array}{r}33 \mathrm{M} \\
\text { Brother }\end{array}$ & 53 & 20 & 64.1 & 50 & 18.86 & 15 & 35.84 & 35 \\
\hline $57 \mathrm{M}$ & $\begin{array}{l}\text { SCC Esophagus } \\
\text { Stage-III } \\
2 \text { Months }\end{array}$ & $\begin{array}{r}28 \mathrm{~F} \\
\text { Daughter }\end{array}$ & 30 & 21 & 16.66 & 28.57 & 53.33 & 9.5 & 26.66 & 61.9 \\
\hline $55 \mathrm{M}$ & $\begin{array}{l}\text { SCC Esophagus } \\
\text { Stage-III } \\
3 \text { Months }\end{array}$ & $\begin{array}{r}35 \mathrm{~F} \\
\text { Daughter }\end{array}$ & 45 & 28 & 45.44 & 35.71 & 17.77 & 32.14 & 33.33 & 35.74 \\
\hline $60 \mathrm{M}$ & $\begin{array}{l}\text { SCC Esophagus } \\
\text { Stage-III } \\
2 \text { Months }\end{array}$ & $\begin{array}{r}20 \mathrm{~F} \\
\text { Daughter }\end{array}$ & 27 & 15 & 70.37 & 26.66 & 14.8 & 26.66 & 55.55 & 26.66 \\
\hline $58 \mathrm{M}$ & $\begin{array}{l}\text { Gastric adeno- } \\
\text { carcinoma } \\
\text { Stage-I } \\
3 \text { Months }\end{array}$ & $\begin{array}{r}20 \mathrm{M} \\
\text { Son }\end{array}$ & 30 & 10 & 43.33 & 40 & 10 & 50 & 63.33 & 40 \\
\hline $40 \mathrm{~F}$ & $\begin{array}{l}\text { Rectal polyps } \\
\text { Stage-I } \\
\text { Mother } \\
4 \text { Months }\end{array}$ & $70 \mathrm{~F}$ & 30 & 36 & 30 & 55.55 & 36.66 & 25 & 33.33 & 47.22 \\
\hline $48 \mathrm{M}$ & $\begin{array}{l}\text { Rectosigmoids } \\
\text { Stage-II } \\
9 \text { Months }\end{array}$ & $\begin{array}{r}22 \mathrm{M} \\
\text { Son }\end{array}$ & 35 & 15 & 22.85 & 26.66 & 8.5 & 73.33 & 86.66 & 46.66 \\
\hline \multirow[t]{2}{*}{$55 \mathrm{M}$} & $\begin{array}{l}\text { Cecum Stage-I } \\
1 \text { Month }\end{array}$ & $\begin{array}{r}30 \mathrm{M} \\
\text { Son }\end{array}$ & 41 & 45 & 24 & 57.14 & 36.58 & 28.57 & 53.65 & 20 \\
\hline & Mean & & 38.2 & 23.4 & 41.03 & 40.17 & 23.96 & 28.75 & 47.88 & 39.13 \\
\hline
\end{tabular}

*Male ** Female 
$9.31 \%$ in healthy unrelated controls (Table 3). The total number of aberrant metaphases constituted $38.20 \%$ of selected metaphases of all cancer patients, $23.40 \%$ in first-degree relatives of patients and $12.50 \%$ in all healthy unrelated controls (Tables 2 and 3). The cancer patients had significantly higher (tcal $>$ ttab at $\mathrm{p}=0.05$ ). aberrant metaphases than the FDRs and controls The FDRs also had significantly higher aberrant metaphases than controls (tcal $>$ ttab at $\mathrm{p}=0.05$ ). The frequency of structural and numerical aberrations were nearly similar in cancer patient and their first degree relatives as the difference was statistically non significant (tcal<ttab at $\mathrm{p}=0.05)$. The acrocentric associations were significantly higher(tcal $>$ ttab at $\mathrm{p}=0.05$ ) in cancer patients as compared to FDRs (Table 4).

\section{DISCUSSION}

In the present study, the aberrations observed in cancer patients were higher than unrelated healthy controls and difference was statistically significant. The aberrations in FDR's were also higher as compared to controls and difference was statistically significant (Table 4). An increased incidence of chromosomal aberrations involving specific chromosomes was observed in lymphocytes of cancer patients and the firstdegree relatives of cancer patients. Terminal deletions, chromatid breaks and chromatid gaps involving A and B group chromosomes were common.

Chromosome loss associated with $1 \mathrm{p}, 3 \mathrm{p}$, chromosome $4,11 \mathrm{q}$ and $12 \mathrm{q}$, and gain of chromosome 12q, 17 and 19 have been reported to be involved in either genesis or progression of the malignancy in esophageal cancers (Pack et al. 1999). Loss of expression of P73 gene and mutations in $\mathrm{N}$-ras oncogene present on chromosome 1 were associated with esophageal tumor development. In all GIT cancer patients and their first-degree relatives, there was loss of 'G' group chromosomes. In 6 cancer patients and 4 FDRs there was loss of chromosome 21. The tumor-suppressor gene TFF1 (Trefoil Factor 1) along with two other Trefoil family member genes is found in a cluster on chromosome 21. Members of the trefoil family are characterized by having at least one copy of trefoil motif, a 40-amino acid domain that contains three conserved disulphides. They are stable secretor/ check proteins expressed in gastrointestinal mucosa. Their functions are not fully defined, but they may protect the mucosa from insults, stabilize the mucus layer, and affect healing of epithelium. Loss of this gene has been previously reported in human GIT tumors (Katoh 2003).

Loss of chromosomes 11 and 12 was seen in cancer patients, but such a loss was not observed in first-degree relatives, except for a single first-degree female relative (Table 1). This relative, with age 70 years, showed a high degree of spontaneous instability. Such instability was not seen in other first-degree relatives with similar age. Chromosomes 11 and 12 harbour groups of genes which are implicated in $\mathrm{V}(\mathrm{D}) \mathrm{J}$ recombination (RAG1, RAG2), tumor suppression (CDK1C, CDKN1B), malignancy of tumors (HRA, TRIM), DNA damage checkpoints (RAD9A, RAD52, CHEK1), neoplasm metastasis (LRP5), checkpoint kinases (ATM), segregation (ZW10), apoptosis (P53AIP1, APAF1, BCL2L14) and transcription factor (MDM2). Loss of whole

Table 3: Gross aberrations observed in lymphocytes of unrelated healthy controls

\begin{tabular}{lccccc}
\hline $\begin{array}{l}\text { Age and } \\
\text { sex of } \\
\text { subject }\end{array}$ & $\begin{array}{c}\text { Aberrant } \\
\text { metaphases } \\
(\%)\end{array}$ & $\begin{array}{c}\text { Metaphases with } \\
\text { numerical } \\
\text { aberrations }(\%)\end{array}$ & $\begin{array}{c}\text { Metaphases with } \\
\text { structural } \\
\text { aberrations }(\%)\end{array}$ & $\begin{array}{c}\text { Metaphases with } \\
\text { acrocentric } \\
\text { associations }(\%)\end{array}$ & $\begin{array}{c}\text { Representative } \\
\text { karyotype }\end{array}$ \\
\hline $51 \mathrm{M} *$ & 11.58 & 3.16 & 1.05 & 7.37 & $46, \mathrm{XY}, \mathrm{g}(1),+\mathrm{ace}$ \\
$49 \mathrm{M}$ & 14.28 & 1.12 & 2.25 & 11.23 & $46, \mathrm{XY}$ \\
$56 \mathrm{M}$ & 14.28 & 2.38 & 1.19 & 10.71 & $46, \mathrm{XY}, \mathrm{terdel}(2)$ \\
$57 \mathrm{M}$ & 10.23 & 1.14 & 1.14 & 7.95 & $46, \mathrm{XY}$ \\
$49 \mathrm{M}$ & 13.79 & 2.30 & 1.15 & 10.34 & $46, \mathrm{XY}, \mathrm{terdel}(3)$ \\
$37 \mathrm{M}$ & 11.02 & 2.36 & 0.79 & 7.87 & $46, \mathrm{XY},+\mathrm{ace}$ \\
$42 \mathrm{M}$ & 16.06 & 2.19 & 2.19 & 11.68 & $46, \mathrm{XY}$ \\
$50 \mathrm{M}$ & 14.43 & 2.06 & 1.03 & 1.34 & $46, \mathrm{XY}$ \\
$29 \mathrm{M}$ & 11.43 & 4.28 & - & 7.14 & $46, \mathrm{XY},+\mathrm{ace}$ \\
$36 \mathrm{M}$ & 11.83 & 3.22 & 1.07 & 9.31 & $46, \mathrm{XY}$ \\
Mean & 12.50 & 2.42 & 1.25 & & \\
\hline
\end{tabular}

* Male 


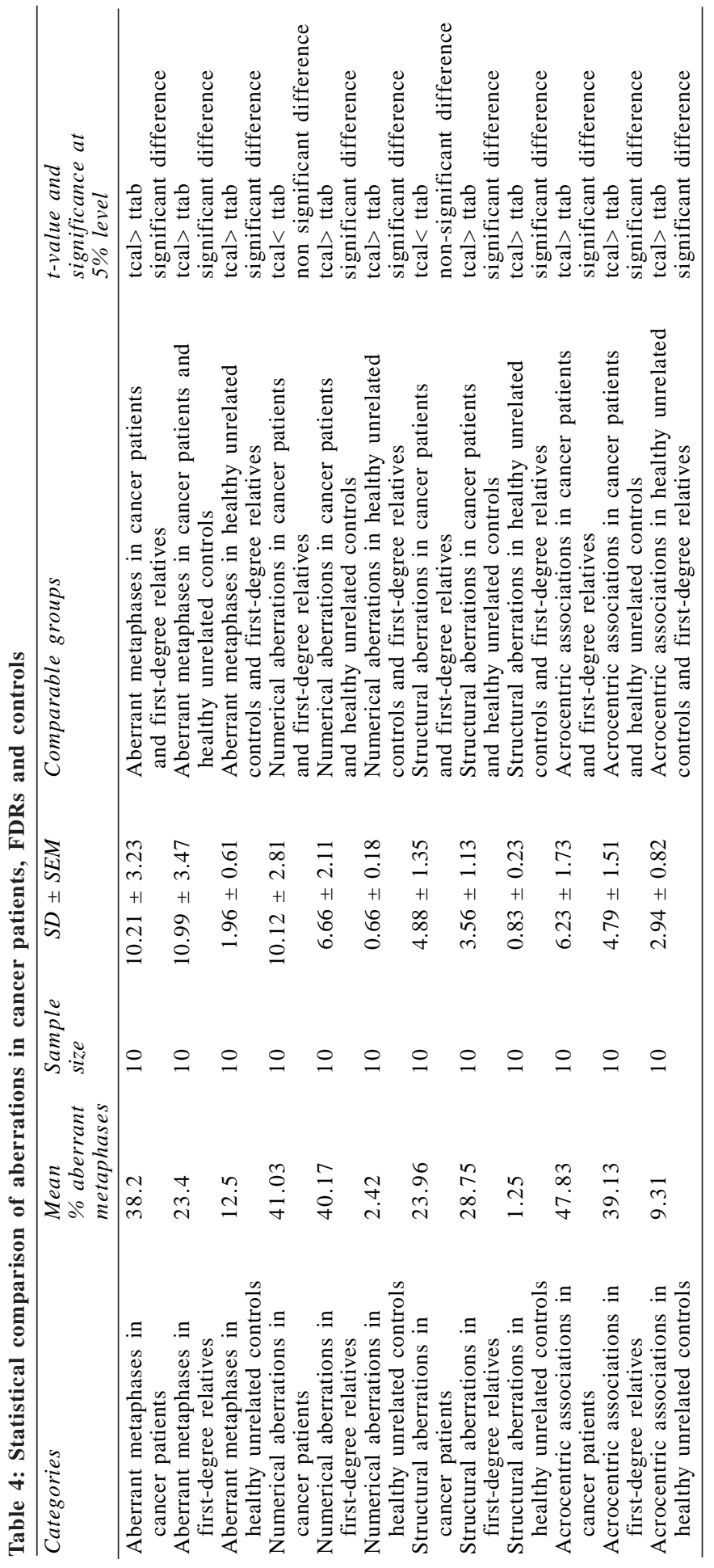


protein-forming machinery indicates a hyped instability with unknown origin in lymphocytes of GIT cancer patients (Mitelman 2005).

Altered chromosomes like $8 \mathrm{p}^{-}, 8 \mathrm{q}^{+}, 11 \mathrm{q}^{-}$and +13 in esophageal carcinoma, inversion $9, \operatorname{del}(7)$ and +8 in gastric cancer and chromosome arrangements characteristic of cancerous lesions have been observed previously in lymphocytes of precancerous lesions suggesting possible cancer predisposition (Jude et al. 2005). Loss of chromosomes 2, 7q, 10, 11, 12, 15, 19, 21 and Y, and gain of chromosomes 3, 4, 10, 19 and 22 have previously been reported in peripheral blood lymphocytes of esophageal cancer patients from same geographical area (Guleria and Sambyal 2003). Chromosomal aberrations involving chromosomes 2, 7, 11, 12, 15, 19, 22 and $\mathrm{X}$ were also reported in peripheral blood lymphocytes of GIT and breast cancers patients (Guleria et al. 2005). Structural and numerical aberrations in chromosome 1, 2, 5, 7, 12, 14, 17, 18 and 21 have been reported earlier also in lymphocytes of GIT cancer patients (Barletta et al. 1993; Dave et al. 1995; Sokova et al. 1997). It has been reported that chromosome segments frequently lost are regions of candidate loci for tumor suppressor genes and those frequently gained are candidate loci of dominantly acting growth regulator genes (Rosenblum-Vos et al. 1993).

Spontaneous chromosomal aberration in invitro cultured peripheral blood lymphocytes of pediatric cancer patients and their healthy firstdegree relatives has earlier been reported which suggests an increase in chromosomal aberration in asymptomatic relatives and points towards its consideration for biomarker studies (Bakshi et al. 1999). Recurrent losses, including 1p, 14q, 10q, $13 q, 15 q, 18 q$ and $22 q$, and gain of $5 p, 12 q, 17 q$ and $20 \mathrm{q}$ have been reported as genetic markers with prognostic potential in gastrointestinal stromal tumors (Chen et al. 2004). Though a database is required to characterize aberrations as a marker of cancer risk (Rossener et al. 2005), there is evidence that increased frequency of chromosomal aberrations in blood lymphocytes is predictor of cancer (El-Zein et al.2005; Boffetta et al. 2007, El-Zein, 2007; Ghosh et al. 2007).

In conclusion, the present study has revealed an increased chromosomal instability on specific chromosomes in lymphocytes of sporadic GIT cancer patients and their first-degree relatives as compared to healthy unrelated controls. In cancer patients the instability is increased probably due to tumor progression. In first-degree relatives of GIT cancer patients, aberrations observed are similar to the aberrations reported in lymphocytes of GIT cancer patients in previous studies (Barletta et al. 1993; Dave et al. 1995; Sokova et al. 1997; Pack et al.1999; Guleria and Sambyal 2003; Chen et al. 2004; Guleria et al. 2005; Jude et al.2005). A high frequency of aberrations involving specific chromosomes harboring particular genes involved, directly or indirectly, in tumorigenesis, indicates a constitutional chromosomal instability. Thus first-degree relatives of sporadic cancer patients are fundamentally a risk group and cytogenetic analysis of lymphocytes as an adjunct to other tests has the potential to be used for surveillance of these subjects.

\section{ACKNOWLEDGEMENT}

UGC grant F.31-267/2005 is gratefully acknowledged.

\section{REFERENCES}

Ankathil R, Jyothish B, Madhavan J, Nair K 1999. Deficient DNA repair capacity: a predisposing factor and high risk predictive marker in familial colorectal cancer. J Exp Clin Cancer Res, 18: 33-37.

Bakshi S, Patel R, Roy S, Alladi P, Trivedi A, Bhatavdekar J, Patel D, Shah P, Rawal M 1999. Chromosomal aberrations in young cancer patients. Cancer Genet Cytogenet, 115: 114-117.

Barletta C, Scillato F, Sega FM, Mannella E 1993. Genetic alteration in gastrointestinal cancer: a molecular and cytogenetic study. Anticancer Res, 13: 23252329.

Benn PA, Perle MA 1986. Chromosome staining and banding techniques. Human Cytogenetics, A Practical Approach. DE Rooney, BH Czepulkowski (Eds.) IRL Press Ltd., Oxford, 54 pp.

Boffetta P, Vander Hel O, Norppa H, Fabianova E, Fucic A, Gundy S, Lazulka J, Cebulska A, Rachtan J, Forni A, Vermeulen R, Bonassi S 2007. Chromosomal aberrations and cancer risk. Results of a cohort study from central Europe. Am J Epidemio, 165 (1):36-43.

Bomme L, Bardi G, Pandis N, Fenger C, Kronborg O, Heim S 1996. Chromosome abnormalities in colorectal adenomas: two cytogenetic subgroups characterized by deletion of $1 \mathrm{p}$ and numerical aberrations. Hum Pathol, 27: 1192-1197.

Bonassi S, Hagmar L, Strömberg U, Montagud AH, Tinnerberg H, Forni A, Heikkilä P, Wanders S, Wilhardt P, Hansteen I, Knudsen LE, Norppa H 2000. Chromosomal aberrations in lymphocytes predict human cancer independently of exposure to carcinogens. Cancer Res, 60: 1619-1625.

Bonassi S, Znaor A, Norppa H, Hagmar L 2004. Chromosomal aberrations and risk of cancer in humans: an epidemiologic perspective. Cytogenet Gen Res, 104: 376-382.

Chen Y, Tzengb C, Lioub C, Changb M, Lib C, Linb C 
2004. Biological significance of chromosomal imbalance aberrations in gastrointestinal stromal tumors. J Biomed Sci, 11: 65-71.

Danes BS 1981. Occurrence of in-vitro tetraploidy in the heritable colon cancer syndromes. Cancer, 48 : 1596-1601.

Dave BJ, Hopwood VL, Hughes JI, Jackson GL, Melillo D, Pathak S 1993. Cytogenetic abnormalities in colon cancer patients: a comparison of T-and Blymphocytes. Anticancer Res, 13: 433-438.

Dave BJ, Hopwood VL, Hughes JI, Mellilo D, Jackson GL, Pathak S 1995. Nonrandom chromosomal abnormalities in lymphocyte cultures of individuals with colorectal polyps and of asymptomatic relatives of patients with colorectal cancer or polyps. Int J Radiat Biol, 68: 429-435.

DiLerina ML, Doneda L, Rizzi R, Larizza L 1987. Cytogenetic instability in a family with gastric cancer recurrence. Cancer Genet Cytogenet, 20: 299-310.

Duesberg P, Fabarius A, Hehlmann R 2004. Aneuploidy, the primary cause of the multilateral genomic instability of neoplastic and preneoplastic cells. IUBMB Life, 56: 65-81.

El-Zein R 2007. Chromosome tell tale of patient risk for new, future cancer. Am Associ Cancer Res c.f.www.mdanderson.org/departments/newsroom/ display.

El-Zein R, Gu Y, Sierra MS, Spitz MR, Strom SS 2005. Chromosomal instability in peripheral blood lymphocytes and risk of prostate cancer. Cancer Epidemiol Biomarkers Prev, 14 (3): 748-752.

Ghosh P, Banerjee M, Chaudhari S, Das JK, Sarma N, Basu A,Giri AK 2007. Increased chromosome aberration frequencies in Bowen's patients compared to non-cancerous skin lesions in individuals exposed to arsenic. Mutat Res, 632: 104-110.

Guanti G, Susca F, Cristofaro G, Caruso ML, Massari S, Porsia R, Stella A, Giorgio I 1990. Cancer family syndrome: cytogenetic investigations, in vitro tetraploidy, and biomarker studies in a large family. $J$ Med Genet, 27: 441-445.

Guleria K, Sambyal V 2003. Chromosomal instability in peripheral blood leucocytes of oesophageal cancer patients. Int J Hum Genet, 3: 179-186.

Guleria K, Singh HP, Singh J, Kaur H, Sambyal V 2005. Non-random chromosomal aberrations in peripheral blood leucocytes of gastrointestinal tract and breast cancer patients, Int J Hum Genet, 5 (3): 205-211.

Hagmar L, Strömberg U, Bonassi S, Hansteen I, Knudsen L, Lindholm C, Norppa H 2004. Impact of types of lymphocyte chromosomal aberrations on human cancer risk results from Nordic and Italian cohorts. Cancer Res, 64: 2258-2263.

Hu N, Goldstein AM, Albert PS, Giffen C, Tang Z, Ding $\mathrm{T}$, Taylor PR, Emmert-Buck MR 2003. Evidence for a familial esophageal cancer susceptibility gene on chromosome 13. Cancer Epidemiol Biomarkers Prev, 12: 1112-1115.

ISCN 2005. An International System for Human Cytogenetic Nomenclature (2005) Recommendations of the International Standing Committee on Human Cytogenetic Nomenclature / editors, Lisa G. Shaffer, Niels Tommerup., Basel ; Farmington, CT : Karger, c2005.

Jin Y, Jin C, Law S, Chu K, Zhang H, Strombeck B, Yuen PWA, Kwong Y 2004. Cytogenetic and fluorescence in situ hybridization characterization of clonal chromosomal aberrations and CCND1 amplification in esophageal carcinomas. Cancer Genet Cytogenet, 148: $21-28$.

Jude ALC, Sasikala K, Chandrasekar TS, Kumar AR, Sudha S, Devi MV and Balachander N 2005. Cytogenetic finding in cancerous and non-cancerous lesions of the digestive system. Int J Hum Genet, 5: 199-203.

Katoh M 2003. Trefoil factors and human gastric cancer (review). Int J Mol Med, 12: 3-9.

Langauer C, Kinzler KW, Vogelstein B 1997. Genetic instability in colorectal cancers. Nature, 386: 623627.

Mitelman F 2005. Mitelman database of chromosome aberrations in cancer. c.f. http://cgap.nci/nih.gov/ chromosomes/Mitelman.

Moorhead PS, Nowell PC, Mellman NJ, Battips DM, Hunngerford DA 1960. Chromosome preparations of leukocytes cultured from human peripheral blood. Exp Cell Res, 20: 613-616.

Pack SD, Karkera JD, Zhuang Z, Pak ED, Balan KV, Hwu P, Park WS, Pham T, Ault DO, Glaser M, Liotta L, Detera-Wadleigh SD, Wadleigh RG 1999. Molecular cytogenetic fingerprinting of esophageal squamous cell carcinoma by comparative genomic hybridization reveals a consistent pattern of chromosomal alterations. Genes Chrom Cancer, 106: $11-17$.

Popat S, Stone J, Houlston RS 2003. Allelic imbalance in colorectal cancer at the CRAC1 locus in early-onset colorectal cancer. Cancer Genet Cytogenet, 145: 70-73.

Rao NM, Joshi NN, Shinde SR, Advani SH, Ghosh SN 1996. Premature separation of centromere and aneuploidy: an indicator of high risk in unaffected individuals from familial breast cancer families. Eur J Cancer Prev; 5: 343-50

Rosenblum-Vos LS, Meltzer SJ, Cox JL, Schwartz S 1993. Cytogenetic studies of primary culture of esophageal squamous cell carcinoma. Cancer Genet Cytogenet, 70: $127-131$

Rossner P, Boffetta P, Capp M, Bonassi S, Smerhovsky Z, Landa K, Juzova D, Sram RJ 2005. Chromosomal aberrations in lymphocytes of healthy subjects and risk of cancer. Environ Hlth Persp, 113: 517-520.

Shiomi H, Sugihara H, Kamitani S, Tokugawa T, Tsubosa Y, Okada K, Tamura H, Tani T, Kodama M, Hattori $\mathrm{T}$ 2003. Cytogenetic heterogeneity and progression of esophageal squamous cell carcinoma. Cancer Genet Cytogenet, 147: 5-61.

Sokova OI, Krichenko OP, Kulagina OE, Konstantinova LN, Chebotarev AN, Fleishman EV 1997. Karyotypic anomalies and chromosomal sites of increased fragility in colorectal cancer. Genetika, 33: 1297-1302 (Article in Russian; Abstract; PMID 9445823).

Tunca B, Egeli U, Zorluoglu A, Yilmazlar T, Yerci O, Kizil A 2000. The expression of fragile sites in lymphocytes of patients with rectum cancer and their first-degree relatives. Cancer Lett, 152: 201-209.

Wu YQ 1991. Genetic etiology of esophageal cancer. VI. Significance of endoreduplication in the cultured lymphocytes from members of high risk cancer families in Linxian country. Zhongh Zhong Liu Za Zhi, 13: 273-275 (Article in Chinese, English Abstract; PMID 1806347).

Zhu Y, Spitz MR, Hsu TC, Wu X 2002. Genetic instability of specific chromosomes associated with a family history of cancer. Cancer Genet Cytogenet, 136: 73-77. 